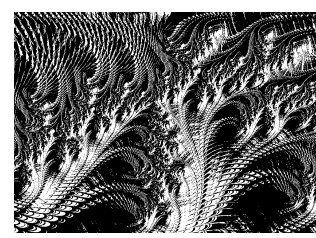

https://doi.org/10.5559/di.30.4.04

\title{
USE OF \\ NORTH KOREA-RELATED \\ YOUTUBE VIDEOS \\ IN SOUTH KOREA: \\ A CASE STUDY OF VIDEOMUG
}

Han Woo PARK

Department of Media \& Communication, Yeungnam University, Gyeong-san, Republic of Korea

UDK: 316.776.33(519.3:519.5):004.738.5

Original scientific paper

Received: January 5, 2020

South Koreans have been producing social media content that sharply divided between conservative and progressive perspectives. This study analyzes a YouTube video clip during a South-North summit and then expands its scope to include the entire set of North Korea-related videos. The video was accused on the presidential petition website of violating South Korea's National Security Law. Despite sparking a debate on the suitability of the video's content among YouTube viewers, the petition did not attract much attention from the general public. Using this clip as a basis, we examine how YouTubers show interest in, reactions to, and engagement with North Korea-related media content using several network metrics and visualizations. Our analysis includes extensive background on South Korea's information policy toward North Korea. Based on our findings, we recommend that the South Korean government use cognitive and communication-oriented profiling-based input when formulating their information policy toward North Korea.

Keywords: South Korea, North Korea, information policy, YouTube, national security law, SBS VideoMug

Han Woo Park, Department of Media \& Communication, Interdisciplinary Graduate Programs of Digital Convergence Business and East Asian Cultural Studies,

Yeungnam University, 280 Dae-hak-ro, Gyeong-san, 
On September 23, 2018, a petition appeared on the South Korean presidential website calling for the government to block access to a YouTube video reporting on the inter-Korean summit on Mt Baekdu and its accompanying comments. The petition ran until October 23, 2018. Surprisingly, it attracted only six signatories. At the time, the Korean Peninsula seemed to be leaving behind the conflicts and antagonism of the previous government, and the political environment under the Moon Jae In government was becoming more peaceful. Three inter-Korean summits and two US-North Korea summits were held in quick succession in 2018. In June 2019, the leaders of South Korea, North Korea, and the United States held historic meetings at the truce village of Panmunjom.

Given the popular response to the petition site, why was the petition about the North Korean-related video ignored? The petition was expected to attract keen public attention as it related to the inter-Korean summit, YouTube, and broadcast news. We argue that a number of socio-political/cultural factors acted as important variables; these include changes in South Koreans' views of North Korea, the demographic profiles of people who visit the petition site, and the usage patterns of YouTube channels.

\section{DETAILS ABOUT PETITION UNDER INVESTIGATION}

The petition was titled "Restrict a YouTube channel that glorifies North Korea with biased reporting" and was posted in the "culture/art/sports/media category" (https://www1.president.go. $\mathrm{kr} /$ petitions $/ 388410$ ? navigation=petitions). A link with the YouTube address of the video (upaOLvpygkA) was posted below the petition. The petition concerns the following. The petitioner watched a video of North Korean leader Kim Jong Un and his South Korean counterpart visiting Mt Baekdu on a channel called "VideoMug" and was shocked to see both its content and how it was edited. The petitioner claims to have been born in 1999 and to be an ordinary college student. The petitioner says that the image of Kim Jong Un presented in this clip was the opposite of what he knew about the leader. The petitioner says that Kim executed his uncle Jang Song Taek and also provoked South Korea in a military way. The petitioner claims that this critical evaluation of Kim is not the result of a particular political orientation but is based on the threat Kim poses to the general public. The petitioner claims to appreciate Moon Jae In's efforts toward unification and peace on the Korean Peninsula but also reminds Moon that South Korea still only has a truce with North Korea, which possesses nuclear weapons. The petitioner argues that what the YouTube clip presents as news about the summit between the two Koreas reflects 
DRUŠ. ISTRAŽ. ZAGREB GOD. 30 (2021), BR. 4, STR. 721-740

PARK, H. W: USE OF NORTH KOREA... the opposite of reality. The title of the video clip under investigation is "The mood maker, Mrs. Ri Seolju, jubilant leader Kim Jong Un," and the main caption is "Storyteller, Seolju and her admirer Jong Un." Several people commented on the clip - for example, saying that "Kim Jong Un's smile at his wife Ri Seolju is lovely." Amid the longstanding military confrontation on the peninsula, the petitioner argues that this kind of favorable treatment of Mr. Kim and his wife causes South Koreans to relax their vigilance. Moreover, it is argued that VideoMug offers only quasi-media, not genuine media, and has been consistently criticized for its inaccuracy and biased opinions, which are designed to create positive feelings toward North Korea. The petitioner sees this as a critical issue directly related to national security, and claims that the Korea Communications Commission (KCC) should impose restrictions on or ban this channel to prevent such biased images from being broadcast. Despite the freedoms guaranteed under Korea's constitution, the petitioner considers freedom of expression that can threaten national security to go beyond the scope of basic human rights.

\section{VIDEOMUG AS CONTENT DISTRIBUTOR ON YOUTUBE IN SOUTH KOREA}

VideoMug is a vertically integrated digital media channel run by the Seoul Broadcasting System (SBS; channel ID: UCM EbRpvuwTbXxGiyDb1mT8w). It began operating in February 2015. SBS is a national South Korean terrestrial television and radio network company (Digital News Lab [DNL], 2019). According to the Korea Press Foundation (Choi, 2019), the main SBS news account has 1.917 million subscribers across four social media platforms (Facebook, Twitter, Instagram, and YouTube). To everyone's surprise, VideoMug has become a threat to SBS's main news account by attracting 1.162 million subscribers. SBS News's YouTube account has 398,302 subscribers, while VideoMug's YouTube has 411,981. By November 18, 2019, VideoMug's YouTube channel has racked up 800,729,422 views. According to DNL (2019), the success of VideoMug is due to changes in the way traditional broadcasting companies deal with current affairs issues, as well as their attitude. The new method is to deliver a variety of news items using exciting images and interesting storytelling. The number of Koreans who consume news on YouTube has increased dramatically. Consistent with this phenomenon, news items are now edited using quick cuts and various angles to prevent viewer boredom.

The 2019 global digital news report published by Oxford 
DRUŠ. ISTRAŽ. ZAGREB GOD. 30 (2021), BR. 4, STR. 721-740

PARK, H. W.

USE OF NORTH KOREA...
Koreans of all generations and is a main channel for news and current events (Newman et al., 2019). The report found that $40 \%$ of South Koreans answered "yes" to "I've watched news-related videos on YouTube over the past week," which is $14 \%$ higher than the average (26\%) for the 38 countries surveyed. Thus, four out of 10 South Koreans use YouTube for news-related videos (which places South Korea fourth out of 38 countries). South Koreans tend to use YouTube regardless of age ( $42 \%$ of those 55 years or older use YouTube); progressive (48\%) and conservative (49\%) Koreans use YouTube more than centrists do (37\%).

\section{SOUTH KOREAN GOVERNMENT'S INFORMATION POLICY TOWARD NORTH KOREA}

South Korea's mass media have often reported on issues related to North Korea and unification in ways that differ depending on their political stance. While the conservative media's perceptions of North Korea's society used to be generally negative due to the hostility between the two nations, progressive newspapers such as Hankyoreh Shinmun and Kyunghyang Shinmun have tended to express fairly moderate or positive views of North Korea. The differences in reporting on North Korea based on differences of political orientation were wide during the Sunshine Policy (1998-2008) and the Panmunjom Declaration periods. The way South Korean mass media discuss North Korea-related matters and the possibility of a unified Korea is beginning to change due to the political and ideological stance of the incumbent president. The leaders of South Korea, North Korea, and the United States held historic meetings in the truce village of Panmunjom. People are watching the current U.S.-North Korea negotiations and wondering whether they will lead to a breakthrough in the peace process on the Korean Peninsula. Reporting on TV, radio, and newspapers has at least shown a desire for a mutually beneficial outcome rather than negativity.

In light of the events that occurred in mid-2020, we cannot be confident that Moon Jae In serves as an important mediator between North Korea and the United States. Nonetheless, the South Korean government and the president's supporters expect the media to contribute significantly to their government's mediating role. The media are recognized as the best means by which to quickly resolve the cultural gaps and heterogeneity between the two Koreas. A seminar series run by South Korean media scholars titled "The Issues of Reporting on North Korea by Domestic Media and the Improvement of Laws and Systems to Expand Inter-Korean Media and Media Exchange" reflects this concern (Yoo \& Kwak, 2019). 
DRUŠ. ISTRAŽ. ZAGREB GOD. 30 (2021), BR. 4, STR. 721-740

PARK, H. W: USE OF NORTH KOREA...
The South Korean media's use of North Korea-related information has been limited under the current administration. The North Korean information that can be used in news coverage is not database-driven. Government authorities are still skeptical about the transparency of North Korea-related information to the media. However, ordinary people can access North Korean information through social media such as Facebook, Twitter, and YouTube. South Koreans cannot be charged for circulating, possessing, or transferring materials under the country's National Security Law simply because they follow, watch, or subscribe to North Korean social media accounts run for propaganda purposes. Article 7 of the National Security Law stipulates that praise or promotion of an enemy organization is required. It bans the establishment of anti-state organizations that jeopardize the country's existence and safety or the basic order of liberal democracy. Those who praise or promote such an organization or its members shall be sentenced to not more than seven years in prison.

The current government has a narrow and closed North Korea-related intelligence management and handling system. The UN Human Rights Council recommended the abolition of the National Security Law; however, though Moon Jae In's government is supposedly progressive, the Justice Ministry and Unification Ministry announced their rejection of the UN's recommendation on January 10, 2018. Thus, traditional media outlets in South Korea are using social media to change how they report on North Koreans and their leaders. For example, a new journalism method rejects clichéd news framing and provides insight instead by using a combination of live action, graphics, satire, and wit to enable the story to explain itself. The coverage includes "hard-boiled" news conveyed through high-quality visuals and compelling storytelling.

However, this use of social media is not well-understood despite its growing popularity. Few studies have focused on the transformation (regulatory) process legacy media have used to regain their lost legitimacy in the social media era and to obtain regulatory acceptance. Some Koreans are reluctant to trust the values and concepts expressed in traditional media reports of the (de)institutionalization process of Korean unification.

\section{SOCIAL MEDIA-MEDIATED COMMUNICATION AND RESEARCH QUESTIONS}

Many studies examine human communication and public opinion in social media spaces. Most findings suggest that social media have become a mobile channel that is quickly increasing public awareness of news by prompting interpersonal communication about news topics (Chong \& Kim, 2020; Ida et 
DRUŠ. ISTRAŽ. ZAGREB GOD. 30 (2021), BR. 4, STR. 721-740

PARK, H. W.:

USE OF NORTH KOREA... al., 2020). The pattern of interactions between social media users may vary according to their engagement with specific issues and channel types. For example, prior studies have examined conversations on social media in various contexts, including public health communication via Twitter during the COVID-19 pandemic (Park et al., 2020), the use of social media among podcast listeners (Kim et al., 2016), the diffusion of cultural memes among YouTubers (Xu et al., 2016), online marketing by cryptocurrency companies (Park \& Lee, 2019), crisis communication during disasters using Facebook (Song et al., 2019), and digital diplomacy between countries (Ittefaq, 2019; Park et al., 2019). Interestingly, hashtags and replies have become important information signals for facilitating interactions among users on social media. Park and Hoffner (2020) have recently revealed the central role played by celebrity-related keywords in public interest campaigns. Park (2018) has compared the textual communications collected from the two most popular YouTube channels on the historic earthquake in South Korea. The study found that information concentration on a few users was higher in professional videos, while community clusters based on two-way information exchange emerged in amateur videos.

Social media such as YouTube often feed users algorithmically tailored content, making it difficult for users to escape their social media circles. Social media users may lie along an ideological divide wherein "like-minded" people tend to form a strongly connected subgroup centered on specific social media channels for the exchange of feelings, opinions, information, and knowledge. This structural process is called "filter bubbles" in the social information and communication sciences (Rieder et al., 2018; Thelwall et al., 2012). Mass interaction through social media has both positive and negative aspects. Shapiro and Park $(2015,2018)$ have found that the replies and comments by people with scientific expertise concerning YouTube videos dealing with global warming showed potential for the development of a public forum but that scientific debates could also be deliberately avoided by engaging in political satire or providing entertainment-driven responses, which denied that possibility. In other words, information circulating on social media is a double-edged sword, with both positive and negative sides.

However, few studies have analyzed video content and communication structures related to North Korea and the use of social media in information sharing (c.f., Park et al., 2021; Park \& Lim, 2020). Learning more about the use and role of YouTube video clips in the public discourse about North Korea among South Koreans requires us to investigate the communication structures represented in VideoMug. 
DRUŠ. ISTRAŽ. ZAGREB GOD. 30 (2021), BR. 4, STR. 721-740

PARK, H. W: USE OF NORTH KOREA...
Three types of research questions - regarding theory, methodology, and policy - were formulated for this study. The theoretical questions are as follows: What do textual messages (including both video titles and their lengthy descriptions) reveal about the possible realities of North Korea and a unified Korea? How do YouTube viewers express their (counter)identities in response to videos based on semantics, topics, and sentiments? The methodological questions were as follows: Can we identify the network characteristic of YouTube video clips over time during the (de)institutional process? What video has the largest audience impact on spillover in the network? The policy-related questions were as follows: How can we apply the findings of a social media conversation network analysis to resolve internal conflicts within South Korea, particularly regarding YouTube video reporting of the inter-Korean summit on Mt Baekdu? Specifically, what types of user engagement policies can be implemented for those who play the key role in facilitating and/or impeding online discussions on reply-to networks?

\section{DATA AND METHOD: VIDEO CLIPS ON NORTH KOREA AND UNIFICATION}

This study examined video clips posed on VideoMug. Out of 1,300 videos posted from July 1, 2018 to May 17 2019, 93 news videos on North Korea were selected. The following queries were used to retrieve the videos: "Kim Jong Un," "North Korea," "unification," "U.S.-North Korea Summit," "South-North Koreas Summit," "Ri Sulju," "Mountain Baekdu," and "Pyongyang." Both textual and networked data were collected using YouTube API embedded in YouTube Data Tools and Webometric Analyst 2.0. Video titles and summaries were downloaded for semantic network analysis. Individual reply-to networks were constructed for each video. The semantic and reply networks helped us to uncover and visualize hidden relationships among YouTube users. Co-commenting patterns can be considered to be proxies for interpersonal exchanges in political discussions. A recent empirical study has revealed that frequent political discussions can help ordinary citizens find more heterogeneous networks, whereas they can lead politically savvy individuals to more homogenous ones (Strauß et al., 2020).

We then conducted a text analysis to extract a set of frequently used words in the videos' titles and summaries as well as user comments. During this process, MeCab was used as a morbidity analyzer for natural language processing. However, to minimize errors in automatic correction, the research team implemented several verification procedures based on criteria selected in advance. Highly relevant words were ex- 
DRUŠ. ISTRAŽ. ZAGREB GOD. 30 (2021), BR. 4, STR. 721-740

PARK, H. W.:

USE OF NORTH KOREA... tracted based on the word frequency distribution. This process mainly extracted words with independent meanings, such as proper and common nouns. Adjectives, adverbs, verbs, and emoticons were also included when appropriate for the analysis framework. The key word group was selected following the procedure in Donohue (1973). Next, an n-gram technique was used to track high-frequency word pairs. N-gram analysis is premised on the process wherein, when events are stored in the human brain, two memories from a similar time period tend to be stored in the same set of neurons (Rashid et al., 2016). Omar et al. (2017) used n-gram data from Google to examine the consistency with which words related to artificial intelligence have been linked over the last few decades. We used Textom.co.kr, a Hadoop-based platform customized for the Korean language. We also used Gephi and NodeXL software for network metrics and visualization.

\section{FINDINGS}

\section{Research question 1}

\section{regarding reactions expressed in user comments}

An examination of the replies posted to the 86 clips of the 93 videos $(92.47 \%)$ shows that, interestingly, the term "fun" appears frequently in both the video titles and descriptions but hardly appears in the public comments. This shows that the meanings provided by the carrying agent, VideoMug, failed to generate an intersubjective meaning among the viewers. Of course, the popularity of this channel indicates that there has been a demand for coverage of North Korea-related news, the supply of which had been insufficient due to the strict government control. To some degree, VideoMug has taken people's cognitive needs into account in its coverage of North Korea, the two Koreas summit, and unification. However, legacy media do not appear to have succeeded in fully breaking with and deinstitutionalizing their traditional practices through social media, despite the fact that it had attracted 769,187 views and 4.9K "likes" (versus 1.3K "dislikes") on April 20, 2019, right before data collection began.

As shown in Table 1, "thinking" appeared frequently, perhaps because people often expressed complex feelings about which position to take. The frequent appearance of words such as "unification," "peace," "denuclearization," "commie," "war," and "economy" reveals that the video relates to various problems in Korean society. The word "peace" occurred in two contexts: it appeared among positive comments wishing for peace and also among negative comments skeptical of a false peace. 
DRUŠ. ISTRAŽ. ZAGREB GOD. 30 (2021), BR. 4, STR. 721-740

PARK, H. W.:

USE OF NORTH KOREA...

? TABLE 1 Top words in terms of concurrence in replies

\begin{tabular}{rllrll}
\hline No & Korean & English & No & Korean & English \\
\hline 100 & 북한 & North Korea & 15 & 국민 & the public \\
74 & 김정은 & Kim Jong Un & 15 & 새끼 & bastard \\
48 & 우리나라 & our country & 13 & 빨갱이 & commie \\
29 & 생각 & thinking & 11 & 비디오머그 & videomug \\
26 & 통일 & unification & 11 & 일본 & Japan \\
23 & 대통령 & President & 10 & 비핵화 & denuclearization \\
22 & 평화 & Peace & 10 & 미화 & glorification \\
21 & 문재인 & Moon Jae In & 10 & 전쟁 & war \\
20 & 미국 & U.S. & 9 & 중국 & China \\
18 & 트럼프 & Trump & 9 & 경제 & economy \\
& & & & & \\
\hline
\end{tabular}

Note: The frequency of each word was standardized by setting the maximum value at 100 in order to allow comparison.

\begin{tabular}{rllll}
\hline No & Korean & English & Korean & English \\
\hline 100 & 문재인 & Moon Jae In & 대통령 & President \\
63 & 북한 & North Korea & 주민 & residents \\
52 & 김정은 & Kim Jong Un & 위원장 & chairman \\
47 & 한반도 & Korean peninsula & 평화 & peace \\
41 & 북한 & North Korea & 핵 & nuclear \\
36 & 백두산 & Baekdu & 천지 & Cheonji \\
36 & 핵 & Nuclear & 포기 & abandonment \\
34 & 빨갱이 & Commie & 새끼 & bastard \\
28 & 김정은 & Kim Jong Un & 개새끼 & son of bitch \\
28 & 천안 & Cheonan & 연평 & Yeonpyeong \\
27 & 천안 & Cheonan & 폭침 & blowing up \\
24 & 연평 & Yeonpyeong & 포격 & bombard \\
24 & 김정은 & Kim Jong Un & 미화 & glorification \\
24 & 북한 & North Korea & 인권 & human right \\
22 & 평화 & Peace & 통일 & unification \\
22 & 북한 & North Korea & 말 & language \\
21 & 역사 & history & 민족 & our people \\
20 & 김대중 & Kim Dae Jung president & 노무현 & Roh Moo Hyun president \\
17 & 적화 & communistic activities & 통일 & unification \\
\hline
\end{tabular}

(1) TABLE 2

Top word-pairs in terms of concurrence in replies
Note: The frequency of each word was standardized by setting the maximum value at 100 in order to allow comparison.

Table 2 and Figure 1 present and visualize the results of the n-gram analysis using a network diagram drawn from the Harel and Koren (2000) layout algorithm in NodeXL. This layout places high-frequency words in the center based on a force-directed algorithm that minimizes overlapping lines according to the positions of the nodes, thereby clarifying the expression of the entire network. The more frequent the word, the darker its coloring. Interestingly, the results of the n-gram analysis reveal that the word pair "Moon Jae In-President" was the most frequent. 
(1) FIGURE 1

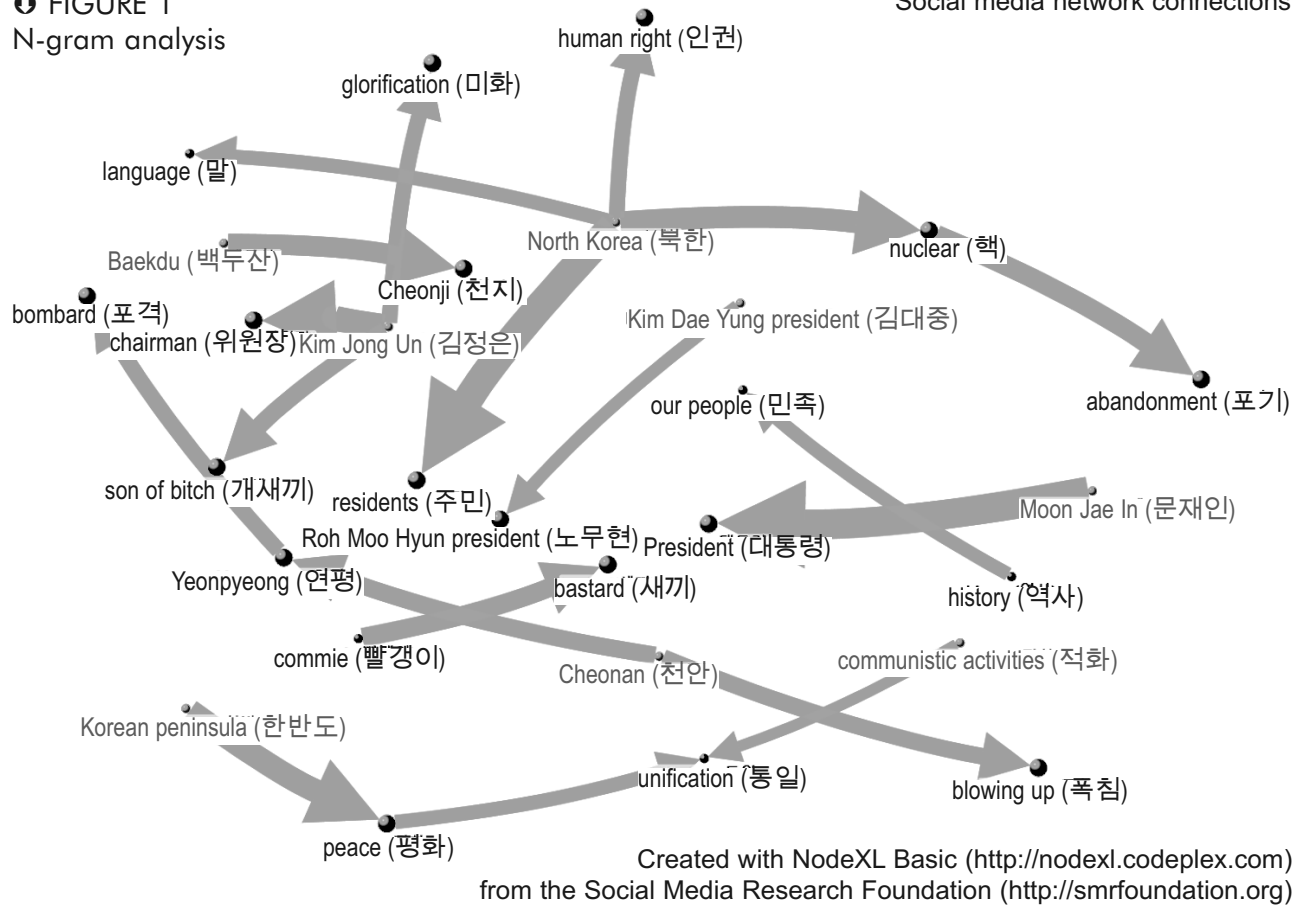

This pair directs viewers to the president, who is the chief executive of South Korea. It is noteworthy that the "CheonanYeonpyeong" pair was frequently used in the replies. "Yeonpyeong" refers to an incident in which North Korea fired artillery shells at South Korea's Yeonpyeong Island on November 23, 2010.

"Cheonan" refers to the March 26, 2010 sinking of a patrol ship, the Cheonan, in an attack by North Korea. The incident left 40 South Korean sailors dead and six others missing. North Korea insists it was not responsible for the incident. The words "North Korea" and "residents" are frequently co-mentioned because viewers often discuss North Korean human rights. Abusive words such as "commie" and "son of a bitch" also appeared often, reflecting negative perceptions of North Korea and its leader Kim Jong Un. The term "Cheonji" refers to Mt Baekdu's lake.

\section{Research question 2 regarding development over time}

The emerging next-order-level "overlay" of communication is particularly important in the case of development over time (Leydesdorff, 2000). People's attention and response levels can be measured using "likes" and views. Although there are a number of weighty issues related to North Korea, videos on food and sports were the second most popular (see Figure 2), 
DRUŠ. ISTRAŽ. ZAGREB GOD. 30 (2021), BR. 4, STR. 721-740

PARK, H. W.:

USE OF NORTH KOREA...

(1) FIGURE 2

Overtime distribution of likes and views into video clips following the Mt Baekdu video, which had the highest number of "likes" and views. Thus, dealing with the most sensitive North Korean issue is the easiest way to deliver news to people. Density value measures the tightness of the degree of connectivity between actors in a network. The density value of those who left comments on the Ronaldo video was 0.006, higher than the 0.004 for two other videos. Assuming 100 people were involved, there were 0.6 conversations on the Ronaldo video. The fine formation of internal congregations can be determined via modularity. This value was also highest for the Ronaldo, at 0.92 , the closest to 1 . However, this video also had the lowest dyadic commenting-replying activity, which may explain the high density and modularity.

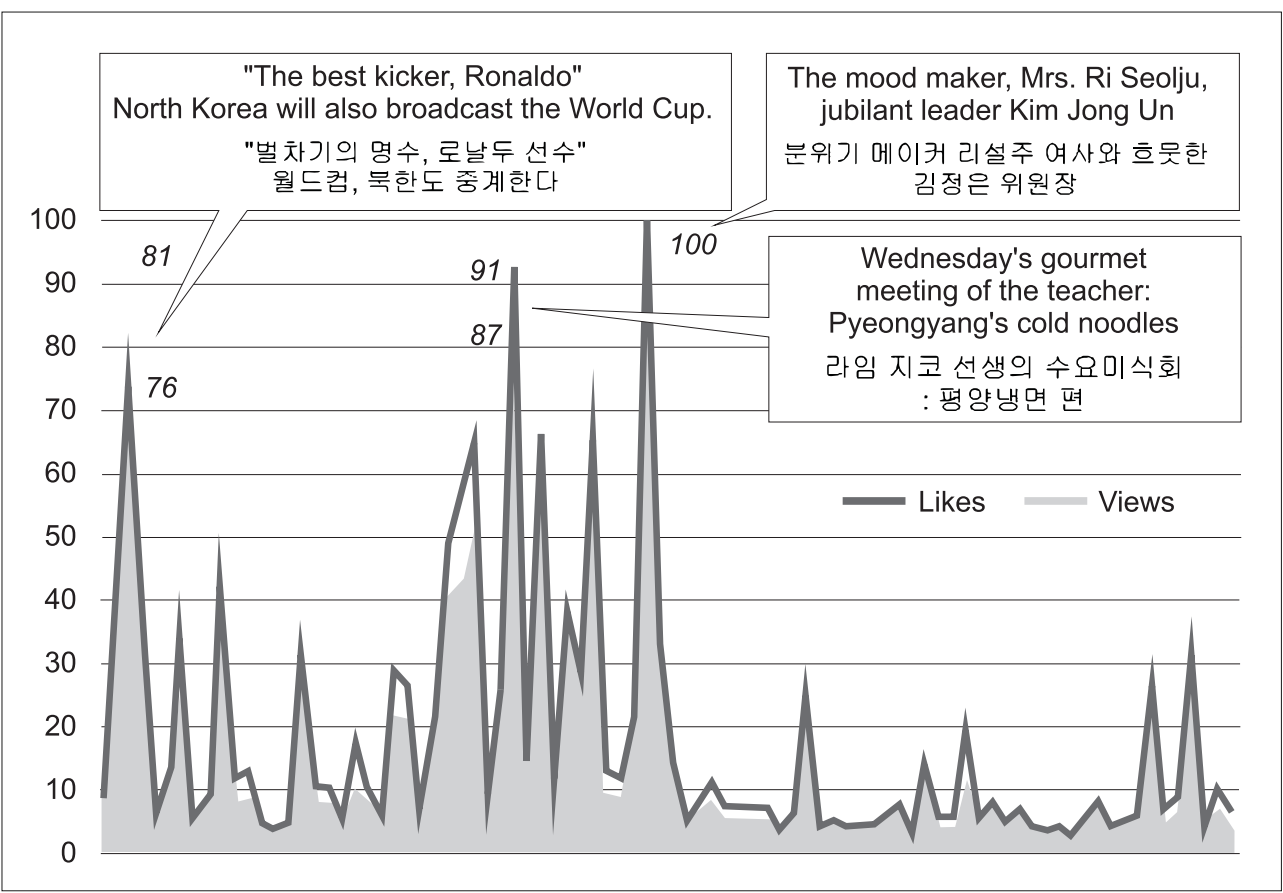

The frequency of both 'likes' and 'views' was standardized by setting the maximum value at 100 in order to allow comparison.

We also examined the underlying participation dynamics that evolved longitudinally in terms of the number of commenters (nodes) and their conversational relations (arrows), as shown in Figure 3. As the figure shows, three videos attracted the most participation (i.e., nodes) and conversation (i.e., arrows). On February 28, 2019, the U.S.-North Korea summit in Hanoi, Vietnam, collapsed. The most talked-about video was posted after the cancellation of the U.S.-North Korea joint statement. When Trump was asked by a reporter whether he would impose additional sanctions on North Korea, he said 
DRUŠ. ISTRAŽ. ZAGREB GOD. 30 (2021), BR. 4, STR. 721-740

PARK, H. W.:

USE OF NORTH KOREA...

(1) FIGURE 3

Overtime distribution of nodes and arrows into video clips
"There are many people in North Korea, and they should live. This is an important issue." Regarding this news, VideoMug provided the relatively neutral caption, "President Trump's view of North Koreans." This spawned another debate, because the caption was interpreted to mean that conservative viewers do not think any more of North Korea than Trump does. The second most talked-about video was about a possible visit to Seoul by Kim Jung Un. At the inter-Korean summit in Pyongyang on September 19, 2018, Kim Jong Un had promised to visit Seoul within the year. This promise was divisive in South Korea. Some people looked forward to it. However, an anti-visit press conference was held featuring a large banner that read "Recruiting an assault commando to arrest Kim Jong Un." This study's main research target is the third most talked-about video.

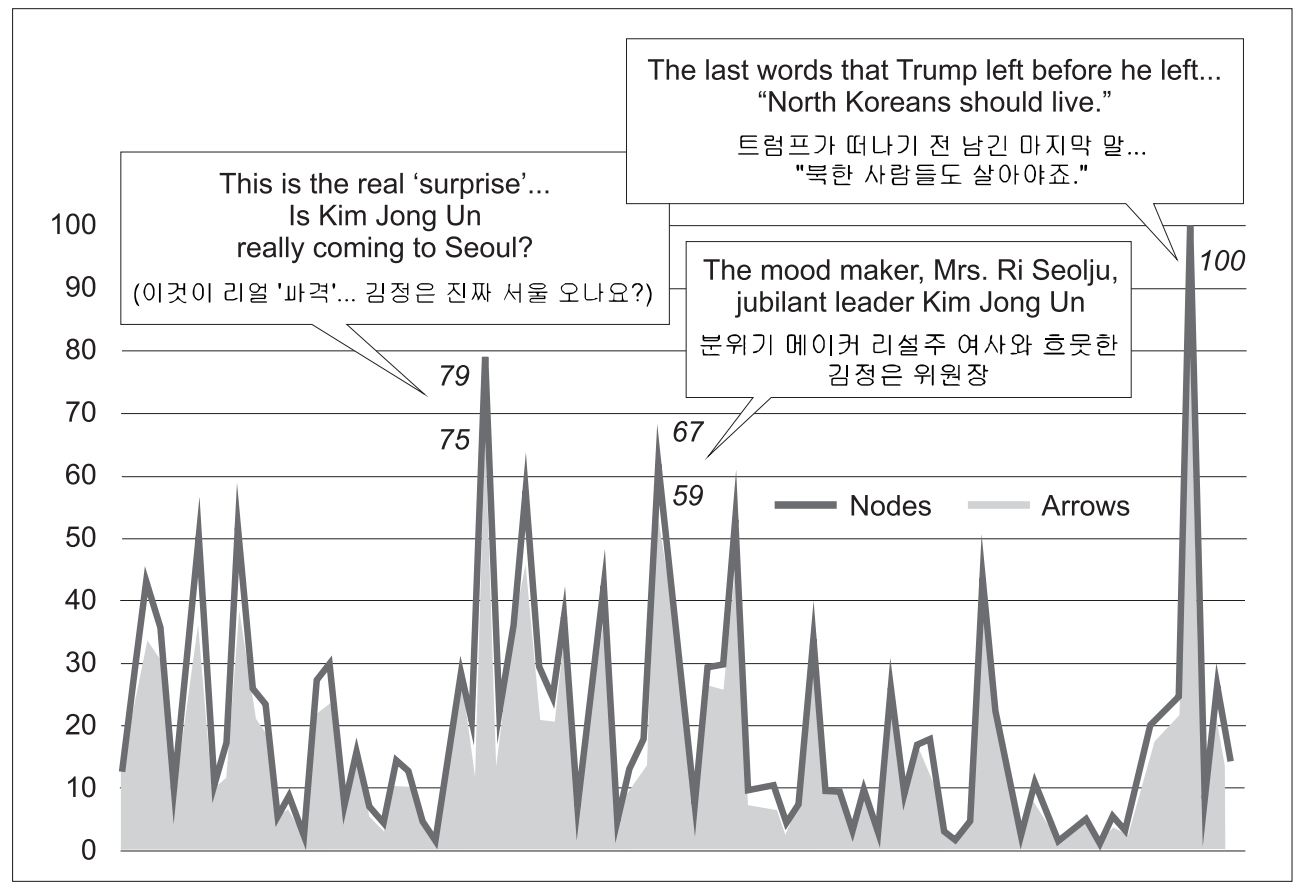

The frequency of both "nodes" and "arrows" was standardized by setting the maximum value at 100 in order to allow comparison.

Measuring an expression sub-network can accurately reflect conversation structures by identifying salient issues. The comment network for the Trump video was not only the most prolific; it also featured the highest frequency of comment exchanges within a subgroup. It had the greatest number of strongly connected component values, at 331 (compared with 260 for the Seoul visit video and 221 for the Mt Baekdu videos). Interestingly, however, the Mt Baekdu video had the highest 
DRUŠ. ISTRAŽ. ZAGREB GOD. 30 (2021), BR. 4, STR. 721-740

PARK, H. W.:

USE OF NORTH KOREA... number of weakly connected components, at 35 (compared to 21 for the Seoul visit video and 22 for the Trump video). Relatively few viewers participated in exchanges regarding the Mt. Baekdu video, resulting in a weak relationship intensity, but there is a high degree of internal differentiation in the relationship patterns. The Mt Baekdu video has the highest asymmetric value, at 0.009 (compared to 0.008 for the Seoul visit video and 0.006 for the Trump video). The most weakly connected cluster consisted of "first-posters" and the "catch-up commenters" who replied to them.

\section{Research question 3 regarding networked information policy}

Figure 4 shows a network diagram of users who participated in the comment thread on the Mt Baekdu video. The Yifan $\mathrm{Hu}$ (2005) algorithm available in Gephi was employed to map out the nodal positions and the distances of their arrows. This algorithm is highly efficient because it provides a visualization quickly. Since the near and far distances between the nodes are calculated, the central and peripheral areas are hierarchically distinguished within a large network of relationships. This allows us to easily grasp the whole structure.

$\curvearrowright$ FIGURE 4

A reply-to network diagram of Mountain Baekdu

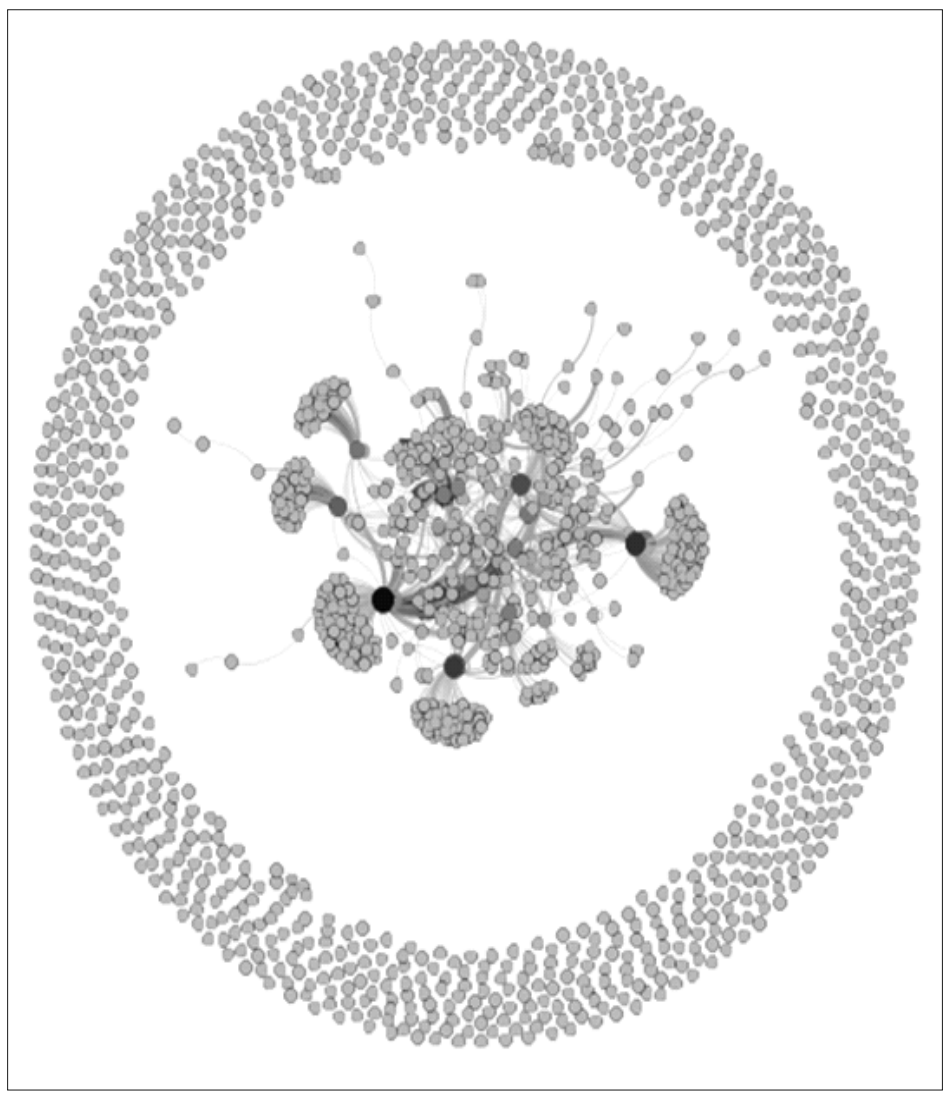


DRUŠ. ISTRAŽ. ZAGREB GOD. 30 (2021), BR. 4, STR. 721-740

PARK, H. W.:

USE OF NORTH KOREA..

(1) TABLE 3

Abbreviated messages in Korean texts and English translations
While quite a few people seem to have never participated in the conversation, active communication is observed in the central part of the concentric circle. In other words, the core groups differed from the general public. This indicates two things. First, viewers on the periphery do not consider VideoMug's storytelling in the video clip to be highly controversial. This clip would have attracted more attention had it been about a more consequential event such as the presidential election. The configuration of the networked communication would have had a polarized bowtie structure. Had the video been about the Olympics or a national disaster, it would have had a tight crowd pattern. Small group-to-group exchanges about the humorous, friendly, and unserious reporting about the North Korean leader were active only along the rim of the network. Many of the people who remained silent may have taken such videos for granted amid the peace between the Koreas and the U.S.-led summit. Others argued that this type of video increases civic unrest and are divisive amid the current inter-Korean standoff period. It is evident that such viewers communicate with each other as "birds of a feather" grouped around big talkers. Table 3 summarizes the postings with high numbers of replies and "likes." Interestingly, the comment with the second-most replies received only two likes. Contrary to the rest of the comments in the Table, the commentator used the term Kkondae in Korean (꼰대) to denounce the old people for criticizing several users who positively perceive the videos friendly to North Korea. The term Kkondae means an old person who tends to condescend and believe that (s)he is always correct and you are stupid. This may be regarded as hate speech based on generational conflict.

\begin{tabular}{|c|c|c|c|}
\hline No & Replies & Likes & Postings \\
\hline 1 & 161 & 1,037 & $\begin{array}{l}\text { 진짜 미쳤다 적국 수장을 이렇게나 미화하구나 } \\
\text { You're so crazy. You're glorifying the head of the enemy country. }\end{array}$ \\
\hline 2 & 17 & 2 & $\begin{array}{l}\text { 절은 사람 중에 미화시킨다 이런 생각 하는 사람 거의 없는데 ... } \\
\text { 미쳤다 꼰대들 어휴 } \\
\text { Few young people think this is a glorification. You're crazy, old men. }\end{array}$ \\
\hline 3 & 13 & 128 & $\begin{array}{l}\text { 세상에 반인륜적 행위란 행위는 전부 다 저지른 김정은을 이렇게 } \\
\text { 포장한다고? } \\
\text { This is how you wrap up Kim Jong Un, who committed every act of } \\
\text { anti-humanizing the world? }\end{array}$ \\
\hline 4 & 7 & 71 & $\begin{array}{l}\text { 자기 국민도 모자라 남한 사람들마저 무자비하게 죽였던 독재자를 } \\
\text { 미화시키는게 당연해졌다니 } \\
\text { I can't believe they take it for granted to glorify the dictator who killed } \\
\text { not only the North Koreans but also the South Koreans mercilessly. }\end{array}$ \\
\hline 5 & 3 & 35 & $\begin{array}{l}\text { 비디오머그 어디서 만드는 거냐 이거 이거 못 쓰겠네 } \\
\text { Who's running the video mugs? Nonsense. }\end{array}$ \\
\hline
\end{tabular}


People have become used to reading messages provided via portal sites or social media on smartphones rather than accessing news or information through newspapers, TV, or magazines. Video clips uploaded on YouTube are more sensory-oriented and attractive to users than simple text. Viewers see provocative and suggestive titles, select only the information they need and wish to consume, and are not interested in the authenticity or source of the information. Online video platforms such as YouTube have been criticized for being channels where North Korean news is circulated and consumed, but few studies have researched media designed to spread North Korea-related information. This study has examined the operation and distribution mechanisms of North Korean news on YouTube and analyzed its ecosystem network using structural data. The findings should assist the formulation of the government's effective countermeasures to deal with online North Korea-related information. In particular, the circularity (up and down) of inter-Korean relations seems to suggest that South Korea needs a social consensus that encompasses various stakeholders, including the government, citizens, civil society, and news organizations.

According to the results of the video analysis, topic groups were divided around stakeholders and issues. Many people participated in the conversations regarding the video clips about Trump's remarks and Kim Jong Un's visit, but sports and entertainment videos attracted more views and "likes." People with similar political orientations or tendencies who gather to experience a collective bond in an online space or to share their opinions with others are likely to express similar opinions. The influence of North Korean information on content users can be explained by the concept of "social sympathy." A chain reaction is created through the transmission and proliferation of North Korea-related information, and users will continue to rely on incomplete information and ignore all contrary evidence. This study did not conduct an in-depth analysis of the contents and context of the YouTube comments or a detailed profiling of the commenters. Thus, it was difficult to identify an authority among the commenters, even though every network tends to have a hub that serves to spread and transmit information. Such networks are unlikely to have a structure that allows random communication between people who hold differing opinions.

In the past, under conservative regimes, South Koreans could be arrested for posting Twitter messages mocking the North Korean regime (Heo, 2012), regardless of the ultimate intention behind the tweet, pursuant to the National Security. Now, it seems that South Koreans not only retweet North 
DRUŠ. ISTRAŽ. ZAGREB GOD. 30 (2021), BR. 4, STR. 721-740

PARK, H. W.:

USE OF NORTH KOREA...
Korea's Twitter account (https://twitter.com/uriminzok), which is called "Between Korean People" (Uriminzokkiri in Korean), but also share North Korea-related videos on YouTube. In September 2019, bars around universities in Seoul prepared to open for business by flying the North Korean flag and displaying pictures of Kim Il Sung and his son Kim Jong Il. Their interiors and exteriors featured North Korean-style propaganda pictures reminiscent of Pyongyang's bustling streets. However, the police were lenient and made no arrests. Given this situation, we can see why the petition about VideoMug's Mt. Baekdu video did not receive much attention. It is hard for the Moon administration to punish such broadcasts for violating the National Security Law.

It is also difficult for the South Korean government to respond effectively to conservative viewers' aggressive criticism of certain YouTube videos. If the owner of an offending YouTube account refuses to voluntarily delete its content, the government can ask Google and YouTube to delete it. The South Korean government has made 281 such requests between 2009 and June 2018 (Kim et al., 2019). Broken down by period, 139 requests were made in the seven-year period from 2009 to 2015 , and 142 requests were made in the three-and-a-half years between 2016 to June 2018. In other words, government content-deletion requests have been increasing since 2016. The government is the most common source of deletion requests (74, or $27.4 \%$ of all requests). The South Korean government also requested the deletion of 12 YouTube channels that distribute North Korean news, including the North Korean government's own public news channel. The government claimed that the channels promoted North Korea and threatened the security of South Korea. However, Google did not honor these requests.

To create effective news and communication policies, the South Korean government may need to understand the role of social media in society beyond labeling them "transitional." The government's "Guideline on Dealing with Restricted Materials and Information on North Korea" was written during the late 1980s and early 1990s, when President Roh Tae Woo was pursuing his northern policy (Song, 2010). The left-wing government of Kim Dae Jung came to power in 1998. It announced a South-North Joint Declaration on June 15 of that year and revised its policy in order to expand the allowable disclosure of North Korea-related material. Afterward, the mood for reconciliation and cooperation between the two Koreas grew, and the use of North Korean materials gained momentum. However, it is difficult to assess whether substantial progress has been made. 
DRUŠ. ISTRAŽ. ZAGREB GOD. 30 (2021), BR. 4, STR. 721-740

PARK, H. W: USE OF NORTH KOREA...
The Moon government shut down the National Intelligence Service's anticommunist investigative functions, and the investigation activities of the nation's public security authorities have been sharply reduced. The number of people arrested for violating the National Security Law has dropped steeply since Moon Jae In took office. Under the conservative regime of President Park Geun Hye from 2013 to 2017, people were convicted for various violations, such as praising or encouraging North Korea, forming and joining an anti-state transfer group, infiltrating or escaping from North Korea, and spying.

The Moon administration faced a conflict with U.S. President Trump when it considered lifting sanctions against North Korea unilaterally. Due to the dynamics of international politics, including the UN sanctions on North Korea, it is difficult for South Korea to provide its own substantial aid to the North. At a time when South Korean liberals are calling for the abolition of the National Security Law, it is also difficult for the government to take a tough stance on North Korea-related YouTube videos and other media. To make matters worse, many social media, including YouTube, are operated by overseas content providers, and the government lacks applicable legal enforcement measures. VideoMug is run by a local broadcaster, but it is impossible to shut it down without triggering petitions. Further study is needed to examine the specifics about how, where, and when such interventions by the Moon administration could occur in policy and legal terms. Despite its limitations, this study provides a very timely case study that furthers our understanding of the quickly changing dynamics of old and new media systems and media pluralism trends in South Korea (c.f. Dwyer \& Hutchinson, 2019).

\section{ACKNOWLEDGEMENT}

The author thanks Dr. Timothy Dwyer and Hwa-Young Song for their valuable assistance in the earlier version of this manuscript and data curation. The data are part of a large dataset also used in another study (Park et al., 2021) that examines infotainment news and narrative styles.

\section{DECLARATION}

To be transparent about a potential conflict of interest, our journal's new policy requires some authors on the list of editors to disclose their editorial position - even if they are not involved in handling the manuscript. As a result, I declare that I am a member of the editorial board. However, I do not benefit from my position in the journal at any point during the submission to publication process. 
Choi, S. Y. (2019). Korea's media company's SNS operation performance. Newspaper E Broadcasting, 580, 58-63. Written in Korean.

Chong, M., \& Kim, H. J. M. (2020). Social roles and structural signatures of top influentials in the \# prayforparis Twitter network. Quality E Quantity, 54, 315-333. https://doi.org/10.1007/s11135-019-00952-z

Digital News Lab (DNL) of SBS (2019). About VideoMug. < https://www. sbsdlab.co.kr $>$ Written in Korean.

Donohue, J. C. (1973). Understanding scientific literature: A bibliographic approach. The MIT Press.

Dwyer, T., \& Hutchinson, J. (2019). Through the looking glass: The role of portals in South Korea's online news media ecology. Journal of Contemporary Eastern Asia, 18(2), 16-32.

Harel, D., \& Koren, Y. (2000). A fast multi-scale method for drawing large graphs. Proceeding of Graph Drawing Conference. https://doi.org/10. 1145/345513.345353

Heo, H. J. (January 12, 2012). Tweeted North Korea, arrested for violating the National Security Law? Civic group "Prosecution intends to control SNS". Pressian. < http://www.pressian.com/news/article?no=105861> Written in Korean.

$\mathrm{Hu}, \mathrm{Y}$. F. (2005). Efficient, high-quality force-directed graph drawing. The Mathematica Journal, 10(1), 37-71.

Ida, R., Saud, M., \& Mashud, M. (2020). An empirical analysis of social media usage, political learning and participation among youth: A comparative study of Indonesia and Pakistan. Quality $\mathcal{E}$ Quantity, 54, 1285-1297. https://doi.org/10.1007/s11135-020-00985-9

Ittefaq, M. (2019). Digital diplomacy via social networks: A cross-national analysis of governmental usage of Facebook and Twitter for digital engagement. Journal of Contemporary Eastern Asia, 18(1), 49-69.

Kim, J. Y., Lee, Y. O., \& Park, H. W. (2016). Delineating the complex use of a political podcast in South Korea by hybrid web indicators: The case of the Nakkomsu Twitter network. Technological Forecasting $\mathcal{E}$ Social Change. 110, 42-50. https://doi.org/10.1016/j.techfore.2015.11.012

Kim, M. J., Chung, C. J., \& Park, H. W. (2019). Harmful content and countermeasures of false information in foreign internet platforms. Korea Press Foundation. Written in Korean.

Leydesdorff, L. (2000). A sociological theory of communication: The self-organization of the knowledge-based society. Universal Publishers.

Newman, N., Fletcher, R., Kalogeropoulos, A., \& Nielsen, R. K. (2019). Digital news report 2019. Reuters Institute.

Omar, M., Mehmood, A., Choi, G. S., \& Park, H. W. (2017). Global mapping of artificial intelligence in Google and Google Scholar. Scientometrics, 113(3), 1269-1305. https://doi.org/10.1007/s11192-017-2534-4

Park, H. W. (2018). YouTubers' networking activities during the 2016 South Korea earthquake. Quality \& Quantity, 52(3), 1057-1068. https:// doi.org/10.1007/s11135-017-0503-x

Park, H. W., \& Lee, Y. J. (2019). How are Twitter activities related to top cryptocurrencies' performance? Evidence from social media net- 
DRUŠ. ISTRAŽ. ZAGREB GOD. 30 (2021), BR. 4, STR. 721-740

PARK, H. W. USE OF NORTH KOREA... work and sentiment analysis. Društvena istraživanja, 28(3), 435-460. https://doi.org/10.5559/di.28.3.04

Park, H. W., \& Lim, Y. S. (2020). Do North Korean social media show signs of change? An examination of a YouTube Channel using qualitative tagging and social network analysis. Journal of Contemporary Eastern Asia, 19(1), 123-143.

Park H. W., Park, S., \& Chong, M. (2020). Conversations and Medical news frames on Twitter: Infodemiological study on COVID-19 in South Korea. Journal of Medical Internet Research, 22(5), e18897. https://doi.org/10. 2196/18897

Park, S., \& Hoffner, C. A. (2020). Tweeting about mental health to honor Carrie Fisher: How \#InHonorOfCarrie reinforced the social influence of celebrity advocacy. Computers in Human Behavior, 110(3), 106353. https://doi.org/10.1016/j.chb.2020.106353

Park, S., Bler, L. M., \& Park, H. W. (2021). The effects of infotainment on public reaction to North Korea using hybrid text mining: Content analysis, machine learning-based sentiment analysis, and co-word analysis. Profesional de la Información, 30(3). https://doi.org/10.3145/epi.2021. may.06

Park, S., Chung, D., \& Park, H. W. (2019). Analytical framework for evaluating digital diplomacy using network analysis and topic modeling: Comparing South Korea and Japan. Information Processing and Management, 56(4), 1468-1483. https://doi.org/10.1016/j.ipm.2018.10.021

Rashid, A. J., Mercaldo, C. Y. V., Hsiang, H. L., Park, S., Cole, C. J., Cristofaro, A. D., Yu, J., Ramakrishnan, C., Lee, S. Y., Deisseroth, K., Frankland, P. W., \& Josselyn, S. A. (2016). Competition between engrams influences fear memory formation and recall. Science, 353(6297), 383-387. https://doi.org/10.1126/science.aaf0594

Rieder, B., Matamoros-Fernández, A., \& Coromina, Ò. (2018). From ranking algorithms to 'ranking cultures': Investigating the modulation of visibility in YouTube search results. Convergence: The International Journal of Research into New Media Technologies, 24(1), 50-68. https://doi. org/10.1177/1354856517736982

Shapiro, M. A., \& Park, H. W. (2015). More than entertainment: YouTube and public responses to the science of global warming and climate change. Social Science Information, 54(1), 115-145. https://doi.org/10.1177/ 0539018414554730

Shapiro, M. A., \& Park, H. W. (2018). Climate change and YouTube: Deliberation potential in post-video discussions. Environmental Communication, 12(1), 115-131. https://doi.org/10.1080/17524032.2017.1289108

Strauß, N., Alonso-Muñoz, L., \& Gil de Zúñiga, H. (2020). Bursting the filter bubble: The mediating effect of discussion frequency on network heterogeneity. Online Information Review, 44(6), 1161-1181. https://doi.org/10.1108/OIR-11-2019-0345

Song, M. S., Jung, K. J., Kim, J. Y., \& Park, H. W. (2019). Risk communication on social media during the Sewol ferry disaster. Journal of Contemporary Eastern Asia, 18(1), 173-200.

Song, S. S. (2010). A study on building cooperation model for the public availability of materials and information on North Korea. Information Management Research, 41(2), 71-93. Written in Korean. https://doi.org/ 10.1633/JIM.2010.41.2.071 
DRUŠ. ISTRAŽ. ZAGREB GOD. 30 (2021), BR. 4, STR. 721-740

PARK, H. W.:

USE OF NORTH KOREA..
Thelwall, M., Sud, P., \& Vis, F. (2012). Commenting on YouTube videos: From Guatemalan rock to el big bang. Journal of the Association for Information Science and Technology, 63(3), 616-629. https://doi.org/10.1002/ asi.21679

Yoo, H. S., \& Kwak, S. H. (2019). An announcement for a Joint Seminar of the Korean Association of Political Communications - Korean Broadcasting Society-Korea Press Association on "the issue of reporting on North Korea by the domestic media and ways to improve the law and system for expanding media and media exchanges between the two Koreas." Korea Press Center. Written in Korean.

Xu, W. W., Park, J. Y., Kim, J. Y., \& Park, H. W. (2016). Networked cultural diffusion and creation on YouTube: An analysis of YouTube memes. Journal of Broadcasting \& Electronic Media, 60(1), 104-122. https://doi. org $/ 10.1080 / 08838151.2015 .1127241$

\section{Upotreba YouTube videozapisa o Sjevernoj Koreji u Južnoj Koreji: studija slučaja o kanalu VideoMug}

Han Woo PARK

Odjel za medije i komunikacije, Sveučilište Yeungnam, Gyeong-san, Republika Koreja

Južnokorejci proizvode sadržaje na društvenim mrežama koji su oštro podijelili korisnike konzervativnih i progresivnih pogleda. Ova studija analizira videoisječak na YouTubeu tijekom sastanka na vrhu Juga i Sjevera, a zatim proširuje svoi doseg kako bi uključila niz videozapisa koji se odnose na Sjevernu Koreju. Video je na predsjedničkoj web stranici, koja objavljuje peticije optuženih za kršenje južnokorejskoga Zakona o nacionalnoj sigurnosti. Unatoč tome što je izazvala raspravu o prikladnosti sadržaja videa među gledateljima YouTubea, peticija nije privukla veliku pozornost šire javnosti. Na temelju ovog videoisječka ispitujemo mrežnim mjerenjima i vizualizacijama kako korisnici YouTubea iskazuju svoj interes i angažman te kakve su im reakcije na medijske sadržaje o Sjevernoj Koreji. Naša analiza uključuje opsežnu pozadinu informacijske politike Južne Koreje prema Sjevernoj Koreji. Oslanjajući se na dobivene nalaze, preporučujemo južnokorejskoj vladi da se posluži spoznajama koje se temelje na kognitivnom i komunikacijski orijentiranom profiliranju u stvaranju njihove informacijske politike prema Sjevernoj Koreji.

Ključne riječi: Južna Koreja, Sjeverna Koreja, informacijska politika, YouTube, Zakon o nacionalnoj sigurnosti, SBS VideoMug

\section{(c) (i) (을}

Međunarodna licenca / International License: 